\title{
A multi-year study of narwhal occurrence in the western Fram Strait-detected via passive acoustic monitoring
}

\author{
Heidi Ahonen ${ }^{1}$, Kathleen M. Stafford ${ }^{2}$, Christian Lydersen ${ }^{1}$, Laura de Steur ${ }^{1}$ \& Kit M. Kovacs ${ }^{1}$ \\ 'Norwegian Polar Institute, Tromsø, Norway; \\ ${ }^{2}$ Applied Physics Laboratory, University of Washington, Seattle, WA, USA
}

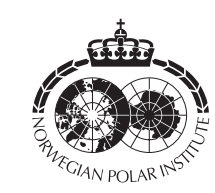

\begin{abstract}
Passive acoustic monitoring (PAM) has proven to be an efficient method for studying vocally active marine mammals in areas that are difficult to access on a year-round basis. In this study, a PAM recorder was deployed on an oceanographic mooring in western Fram Strait $\left(78^{\circ} 50^{\prime} \mathrm{N}, 5^{\circ} \mathrm{W}\right)$ to record the acoustic presence of narwhals (Monodon monoceros) over a 3-yr period. Acoustic data were recorded for 14-17 $\mathrm{min}$ at the start of each hour from 25 September 2010 to 26 August 2011, from 2 September 2012 to 11 April 2013 and from 8 September 2013 to 27 April 2014. Pulsed and tonal signals, as well as echolocation clicks, were detected throughout the recording periods, demonstrating that this species is present in this region throughout the year. Generalized linear mixed-effect models showed a negative correlation between the acoustic presence of narwhals and very dense sea-ice cover ( $\geq 90 \%)$. Surprisingly, a positive correlation was found between the acoustic presence of narwhals and the presence of warm Atlantic Water in the area. Available data suggest that there might be a unique stock of narwhals in the Eurasian sector of the Atlantic Arctic that do not exhibit the "traditional" narwhal pattern of seasonal migration between coastal summering areas and offshore wintering grounds, but rather remain resident year-round in deep, offshore waters.
\end{abstract}

Keywords

Arctic; echolocation; Monodon monoceros; seasonal distribution; vocalization; whales

\section{Correspondence}

Heidi Ahonen, Norwegian Polar Institute, Fram Centre, PO Box 6606 Langnes, NO-9296, Tromsø, Norway. E-mail: heidi.ahonen@npolar.no

\begin{abstract}
Abbreviations
AURAL: autonomous underwater recorder for acoustic listening; AW: Atlantic Water; EGC: East Greenland Current; GAMM: generalized additive mixed-effect model; GLMM: generalized linear mixed-effect model; NSIDC: National Snow and Ice Data Centre; PAM: passive acoustic monitoring; PW: Polar Water; WSC: West Spitsbergen Current
\end{abstract}

\section{Introduction}

The narwhal (Monodon monoceros) is one of three Arctic endemic cetaceans alongside the white whale (Delphinapterus leucas) and the bowhead whale (Balaena mysticetus). The global range of the species occurs from north-eastern Canada to western Russia within the Atlantic Arctic. At least five subpopulations (stocks) have been suggested to exist west of Greenland (HeideJørgensen, Richard et al. 2013), whereas the number of subpopulations is unknown for the area east of Greenland. The populations of narwhals west and east of Greenland have been geographically isolated at least since the end of the last glaciation some 10000 years ago (Heide-Jørgensen et al. 2015). All narwhal populations are thought to be migratory. Those populations that have been studied show long-distance migrations between coastal summering grounds and offshore wintering areas (e.g., Heide-Jørgensen et al. 2002; Heide-Jørgensen et al. 2003; Laidre et al. 2004; Heide-Jørgensen, Richard et al.
2013; Heide-Jørgensen et al. 2015). These migrations appear to follow strict seasonal timings and routes. The most extensively studied narwhal populations, which reside in north-eastern Canada and West Greenland, are known to feed intensively during winter, and show interannual fidelity to specific offshore feeding locations in Baffin Bay and Davis Strait (Heide-Jørgensen \& Dietz 1995; Dietz et al. 2001; Heide-Jørgensen et al. 2002; Heide-Jørgensen et al. 2003; Laidre et al. 2003; Laidre et al. 2004; Heide-Jørgensen, Richard et al. 2013). During the summer months, narwhals are found in coastal areas in ice-free bays and fjords in the Canadian Arctic Archipelago and in West Greenland (Heide-Jørgensen et al. 2002; Heide-Jørgensen et al. 2003; Heide-Jørgensen, Richard et al. 2013; Heide-Jørgensen et al. 2015). Recent satellite tracking studies have confirmed that animals return to the same summering grounds and that there is limited exchange of individuals between different summering grounds (Heide-Jørgensen, Richard et al. 2013; Heide-Jørgensen et al. 2015). Dietary studies suggest 
that narwhals feed little during summer (e.g., Laidre $\delta$ Heide-Jørgensen 2005), but a recent satellite tracking study that included diving data found that narwhals do deep dives during all seasons, suggesting that some foraging takes place year-round (Watt et al. 2017). In East Greenland, narwhals have been satellite tracked only from the Scoresby Sound fjord system (Heide-Jørgensen et al. 2015). These animals showed typical migration patterns, moving between coastal summering and offshore wintering areas, as well as site fidelity to summering grounds, similar to subpopulations west of Greenland.

Little is known about the distribution and behaviour of narwhals in the North-East Atlantic, especially in offshore areas of the Greenland Sea and Fram Strait. This is largely due to the difficulty of studying this cryptic species in an environment dominated by sea ice, challenging weather conditions and, in the winter, the polar night. No satellite tagging studies have been conducted in these offshore areas and the few available observations of narwhals in the Greenland Sea and Fram Strait come mainly from historical whaling records (Dietz et al. 1994). However, a recent aerial survey carried out in August 2015 in the ice north of Svalbard found significant numbers of narwhals deep into the Arctic ice, north of the shelf break, which might belong to the same stock as animals in Fram Strait and the Greenland Sea (Vacquié-Garcia et al. 2017). The presence of heavy pack ice during much of the year in many parts of this region makes shipbased visual surveys difficult. One way of effectively studying such cryptic species in logistically challenging areas is to use PAM. Deploying hydrophones that record year-round at high latitudes has provided novel information on many Arctic species, including bearded seals (Erignathus barbatus), white whales (Delphinapterus leucas) and bowhead whales (Balaena mysticetus) (e.g., Moore et al. 2012; Stafford, Moore et al. 2012; Stafford et al. 2013; MacIntyre et al. 2015; Ahonen et al. 2017; Stafford et al. 2018). Narwhal acoustics are less often studied compared to other Arctic species, but they are suitable subjects for PAM because they are vocally active. Narwhals produce echolocation clicks and buzzes (very short inter-click interval echolocation) as well as pulsed and tonal signals over a broad range of frequencies, including the lower frequencies often used in long-term PAM programmes (Ford \& Fisher 1978; Shapiro 2006; Marcoux, Auger-Methe, Chmelnitsky et al. 2011; Stafford, Laidre et al. 2012; Marcoux et al. 2017).

In this study, PAM technology was applied to (1) examine the occurrence of narwhal in western Fram Strait on seasonal and interannual time scales and (2) to determine the possible relationship between environmental variables and the presence of this species in this region. Results are considered in light of current and future anthropogenic activity in this area (e.g., shipping traffic and oil and gas exploration) and how changes in the Arctic environment might influence this endemic species.

\section{Material and methods}

\section{Instrumentation and deployment location}

An AURAL M2 recorder (Multi-Électronique Inc.; system sensitivity of $-155 \mathrm{~dB}$ re $1 \mathrm{~V} / \mu \mathrm{Pa}$ ) was deployed on an oceanographic mooring (F13) in western Fram Strait as part of a long-term monitoring programme. The mooring (maintained annually by the Norwegian Polar Institute) is situated at $78^{\circ} 50^{\prime} \mathrm{N}$ and $5^{\circ} \mathrm{W}$ (Fig. 1) on the slope of the continental shelf at a bottom depth of ca. 1015 $\mathrm{m}$. This mooring is part of an array of six moorings of the Fram Strait Arctic Outflow Observatory programme (see www.npolar.no/framstrait; Fig. 1). The AURAL was installed at a target depth of $75 \mathrm{~m}$. The Fram Strait is the main gateway for the exchange of sea ice, freshwater and heat between the Arctic Ocean and the North-East Atlantic. Warm AW flows northward in the WSC (Mosby 1962), while cold PW and sea ice are transported southward in the EGC (Aagaard \& Coachman 1968). Additionally, significant recirculation of AW within Fram Strait occurs between approximately $76^{\circ}$ and $81^{\circ} \mathrm{N}$, making this region very dynamic and oceanographically complex (Bourke et al. 1988). The study area is seldom free of ice and the distance from the AURAL location to the ice edge was over $100 \mathrm{~km}$ for most months for which data were analysed in this study.

\section{Acoustic data and narwhal signal detections}

Sampling rate, duty cycle and recording time varied somewhat among the three recording periods selected for this study: in 2010-11, acoustic data were recorded from 10-8192 Hz (16 384 samples/s) on a duty cycle of $14 \mathrm{~min}$ at the start of each hour; for 2012-13 and 2013-14, data were recorded from 10-16384 Hz (32 768 samples/s) on a duty cycle of $17 \mathrm{~min} / \mathrm{hr}$. Data were recorded from 25 September 2010 to 26 August 2011 , from 2 September 2012 to 11 April 2013 and from 8 September 2013 to 27 April 2014. Battery life was the limiting factor for these instruments; the longer duty cycle during 2012-13 and 2013-14 resulted in shorter data collection periods.

Spectrograms of each acoustic file were generated for analyses (10-8000 Hz, FFT 2048/4096, overlap 75\%, Hanning window) and the presence (or absence) of narwhal signals (pulsed and tonal signals, as well as echolocation 

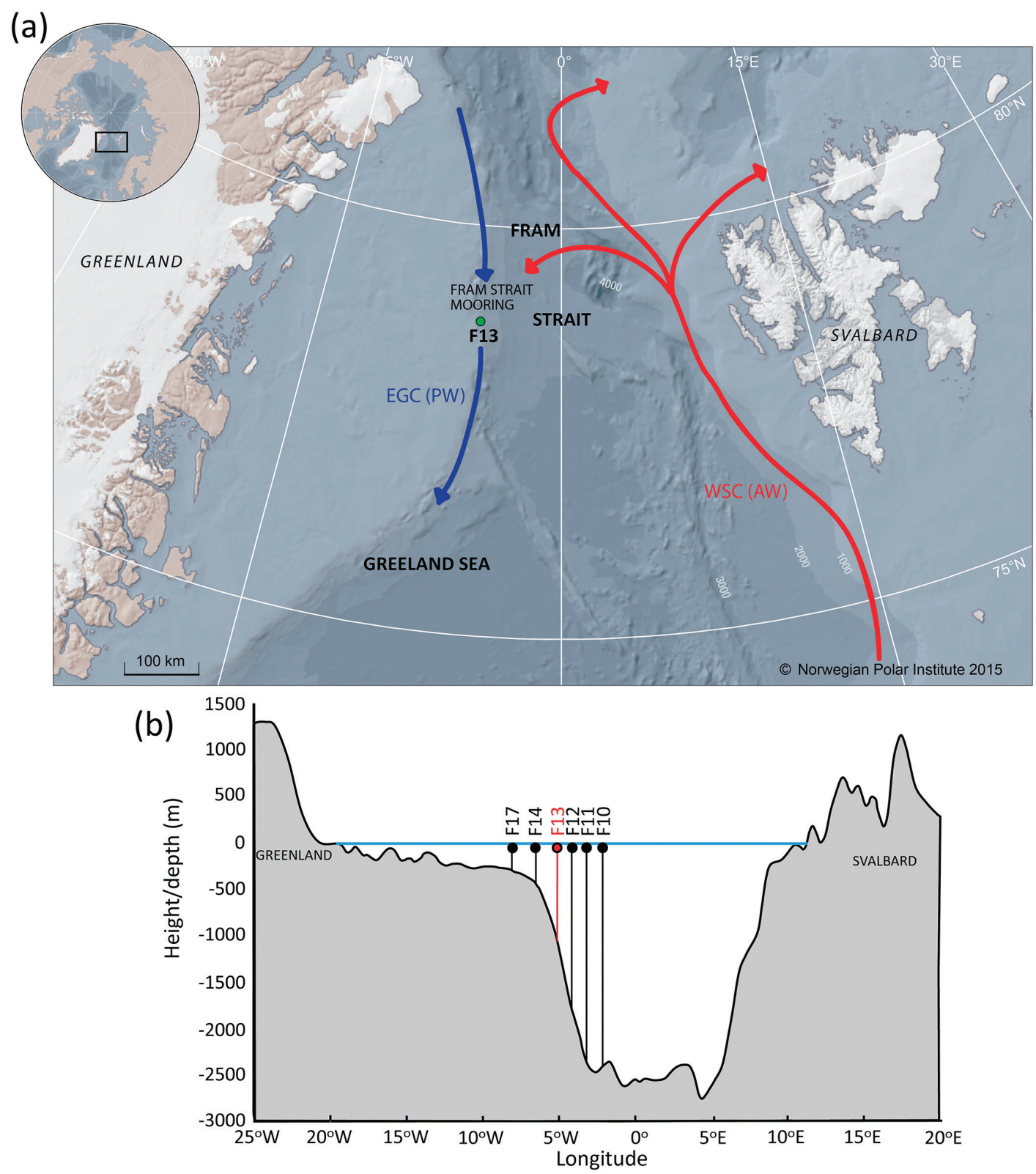

Fig. 1 (a) Location of the Fram Strait oceanographic mooring (F13) instrumented with an AURAL M2 recorder (green dot). Red arrows indicate the WSC that brings warm AW northwards, while blue arrows indicate the EGC, which transports cold PW and sea ice southwards. Different shades of grey indicate different water depths (depth classes in metres are shown with white numbers). (b) Cross-section showing the mooring array in Fram Strait. The F13 mooring is situated on the slope of the continental shelf at a bottom depth of ca. $1015 \mathrm{~m}$; the AURAL is installed at a depth of $75 \mathrm{~m}$. Temperature data from these three moorings were used to calculate the percentage of AW in the upper $500 \mathrm{~m}$.

clicks) was noted for each acoustic file. If visual inspection did not provide an unambiguous "yes/no" for acoustic presence, the corresponding sound files were listened to in order to classify the sounds correctly. Narwhals and white whales produce sounds within overlapping frequency ranges and therefore distinguishing between these two can be difficult if both species are present in acoustic recordings (Marcoux, Auger-Méthé \& Humphries 2011; Stafford, Laidre et al. 2012; Frouin-Mouy et al. 2017). However, white whales are not known to occur in this area. Furthermore, as white whales produce echolocation clicks ranging from 30 to $120 \mathrm{kHz}$ (Sjare \& 
Smith 1986; Roy et al. 2010), the low frequency data used in this study would not record these higher frequency clicks. The date and hour of each narwhal detection were used to examine intra- and interannual variation and to model acoustic presence with respect to environmental variables and light regime.

\section{Environmental variables and light regime}

Three environmental variables were extracted at a daily resolution: (1) the percentage of ice cover within $30 \mathrm{~km}$ of the mooring site, (2) the distance to the ice edge from the mooring site and (3) the percentage (i.e., presence) of AW in the upper $500 \mathrm{~m}$.

Daily sea-ice concentration data $\left(12.5 \mathrm{~km}^{2}\right.$ resolution through 2010-11, $25 \mathrm{~km}^{2}$ resolution thereafter) were downloaded from the NSIDC for each year (Cavalieri et al. 2014). The zonal statistics toolbox in ArcMap 10.0 (ESRI 2011, ArcGIS Desktop: Release 10, Environmental Systems Research Institute) was used to determine mean daily sea-ice concentration (ice cover in \%) within a $30-\mathrm{km}$ radius around the mooring location. Daily sea-ice-extent images (Sea Ice Index data) were also downloaded from NSIDC (Fetterer et al. 2017) and used to calculate minimum distance $(\mathrm{km})$ from the AURAL to the ice edge (defined by the minimum 15\% concentration contour, NSIDC). Daily GeoTIFF files for the Northern Hemisphere were downloaded for each recording period and processed in the statistical software package $\mathrm{R}$ using "rgdal" and "raster" libraries. Greater positive distance to the ice edge means that the mooring was deeper in the ice, whereas negative distances indicate that the mooring was in open water.

The percentage of AW and PW in the upper $500 \mathrm{~m}$ was determined. These two water masses are the main water masses above $500 \mathrm{~m}$ and temperature can be used to distinguish between them in this depth range (see, e.g. Fig. 2 in Beszczynska-Möller et al. 2012). Instruments measured temperature at $5 \mathrm{~min}$ and $20 \mathrm{~min}$ intervals (SBE37 MicroCAT and AADI RCM9/11, respectively) at target depths of 50, 250 and $1000 \mathrm{~m}$ on three oceanographic moorings (F13, Fl2 and F11) from the Fram Strait Arctic Outflow Observatory. The AURAL was placed on mooring F13 (at $5^{\circ} \mathrm{W}$ ); moorings F12 (at $4^{\circ} \mathrm{W}$ )

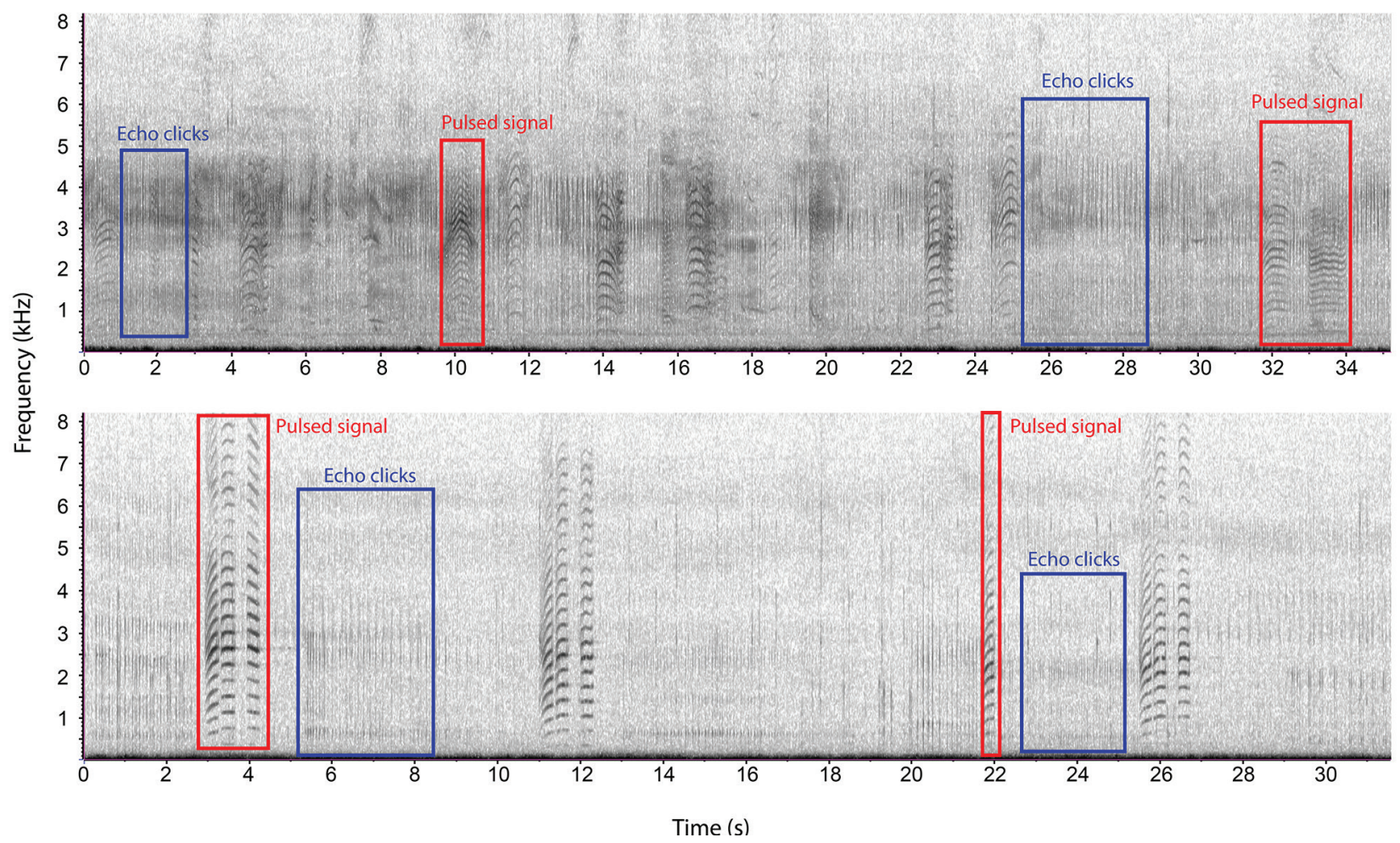

Fig. 2 Spectrogram showing narwhal pulsed signals and echolocation clicks (1024 point fast Fourier transform, 50\% overlap, Hann window). Acoustic files were displayed as spectrograms and visually screened for narwhal signals. Examples of both pulsed signals (red boxes) and echolocation clicks (blue boxes) are shown on the spectrograms. 
and F1 $1\left(\right.$ at $\left.3^{\circ} \mathrm{W}\right)$ were situated at the same latitude, but east of F13 (Fig. 1). Daily averaged temperature records were first interpolated linearly in the vertical and then adjusted to match vertical hydrographic profiles to introduce realistic stratification (as described by de Steur et al. 2009). These vertical profiles were then linearly interpolated in the horizontal ( $5 \mathrm{~km}$ distances). The amount of AW was determined as the fraction of the water within the section between $5^{\circ} \mathrm{W}$ and $3^{\circ} \mathrm{W}$, which has a temperature $>0^{\circ} \mathrm{C}$. Water with temperatures $\leq 0^{\circ} \mathrm{C}$ was defined as PW. Note that this crude classification of AW also contains Arctic Atlantic Water, that is, AW that has circulated for some time and has been mixed to some extent while in the Arctic Ocean.

In addition, solar zenith angle (angle between the zenith and the centre of the sun, degrees) was extracted hourly to take into account the light regime in the analysis. Daylight was defined as having zenith values $<90^{\circ}$ and darkness was defined as zenith values $\geq 108^{\circ}$. Twilight was divided into three zones: civil $\left(\geq 90^{\circ}\right.$ and $\left.<96^{\circ}\right)$, nautical $\left(\geq 96^{\circ}\right.$ and $\left.<102^{\circ}\right)$ and astronomical $\left(\geq 102^{\circ}\right.$ and $\left.<108^{\circ}\right)$.

\section{Model design}

GLMMs for zero-inflated, overdispersed count data were run in $\mathrm{R}$ (package glmmADMB) to determine the possible influence of ice cover (\%), distance to the ice edge $(\mathrm{km})$ and the presence of AW (percentage of AW water in the upper $500 \mathrm{~m}$ ) on the acoustic presence of narwhals (hrs/day) in western Fram Strait. Ice cover was used as a categorical variable with three defined levels: "ice free" $(<15 \%)$, "broken ice" ( $\geq 15 \%$ to $<90 \%)$ and "solid ice" $(\geq 90 \%)$. By defining ice cover as a categorical variable, it could be included in the same model with distance to ice edge while avoiding issues of correlation between these two variables. During all three years of sampling, only 11 days had ice cover $<15 \%$, and these days were all within one recording period (from 21 September to 1 October 2013). Consequently, only two ice-cover categories were included in the model runs: "broken ice" (<90\%) and "solid ice" ( $\geq 90 \%)$. The global model contained percentage of AW water in the upper $500 \mathrm{~m}$, distance to ice edge and ice-cover category as predictor variables, as well as their interactions. Recording period was included as a random effect in the model. From the global model, Akaike's information criterion was used to select the best-fit model from all possible parameter combinations (package MuMIn).

The acoustic presence of narwhals in relation to variation in light regime was examined using GAMM (package mgcv in R). Hourly presence was included in the model as a response variable, (spline-based) smoothed solar zenith angle and month were included as explanatory variables and recording period was included as a random effect.

\section{Results}

\section{Seasonal and annual occurrence of narwhal signals}

A total of 18855 files (4940 h) were screened for narwhal acoustic signals. Pulsed and tonal signals, as well as echolocation clicks of narwhals (Fig. 2), were detected throughout each recording period (except for April 2013, which had only 11 days of recordings). Both intra- and inter-annual variations in acoustic presence were observed (Figs. 3, 4). In 2010-11, narwhals were recorded in every month from the beginning (25 September 2010) to the end of the recording (26 August 2011), demonstrating that this species was present in the region throughout the year (Figs. 3, 4a). Seven out of the 12 months during the 2010-11 recording period had $>50 \%$ of days with narwhal signals (at least $1 \mathrm{hr}$ with detections each day). November, March and April had $\leq 10$ days with narwhal detections (Fig. 4a) in this same recording period. Only six days of data were recorded in September 2010, but narwhal signals were detected during all of these days, almost every hour (>22 hr/day). In 2012-13, the recording started at the beginning of September and narwhals were detected almost every hour through until the beginning of November (Fig. 4b). Five out of eight recorded months in this period had more than $50 \%$ of days with narwhal signals. Narwhal signals were not detected in April 2013 (Figs 3, 4b). In 2013-14, narwhals were detected in every month and five out of 8 months had more than $50 \%$ of days with narwhal signals. September 2013 and April 2014 had the fewest days with detections (<10 days with detection/month, Fig. 4c).

For all three recording periods, April was the month with fewest detections (Figs. 3, 4). Peak numbers of detections were recorded in August 2010, September 2010 and 2012 and October 2010, 2012 and 2013. Detection rates were also relatively high for February for all recording periods (monthly average $>7 \mathrm{hr} /$ day) and for March 2014 (monthly average 11 hr/day) and July 2011 (monthly average $7 \mathrm{hr} /$ day).

\section{Narwhal occurrence in relation to environmental variables and light regime}

Daily narwhal detection (hr/day) in relation to ice cover, distance to ice edge and percentage of AW in the 


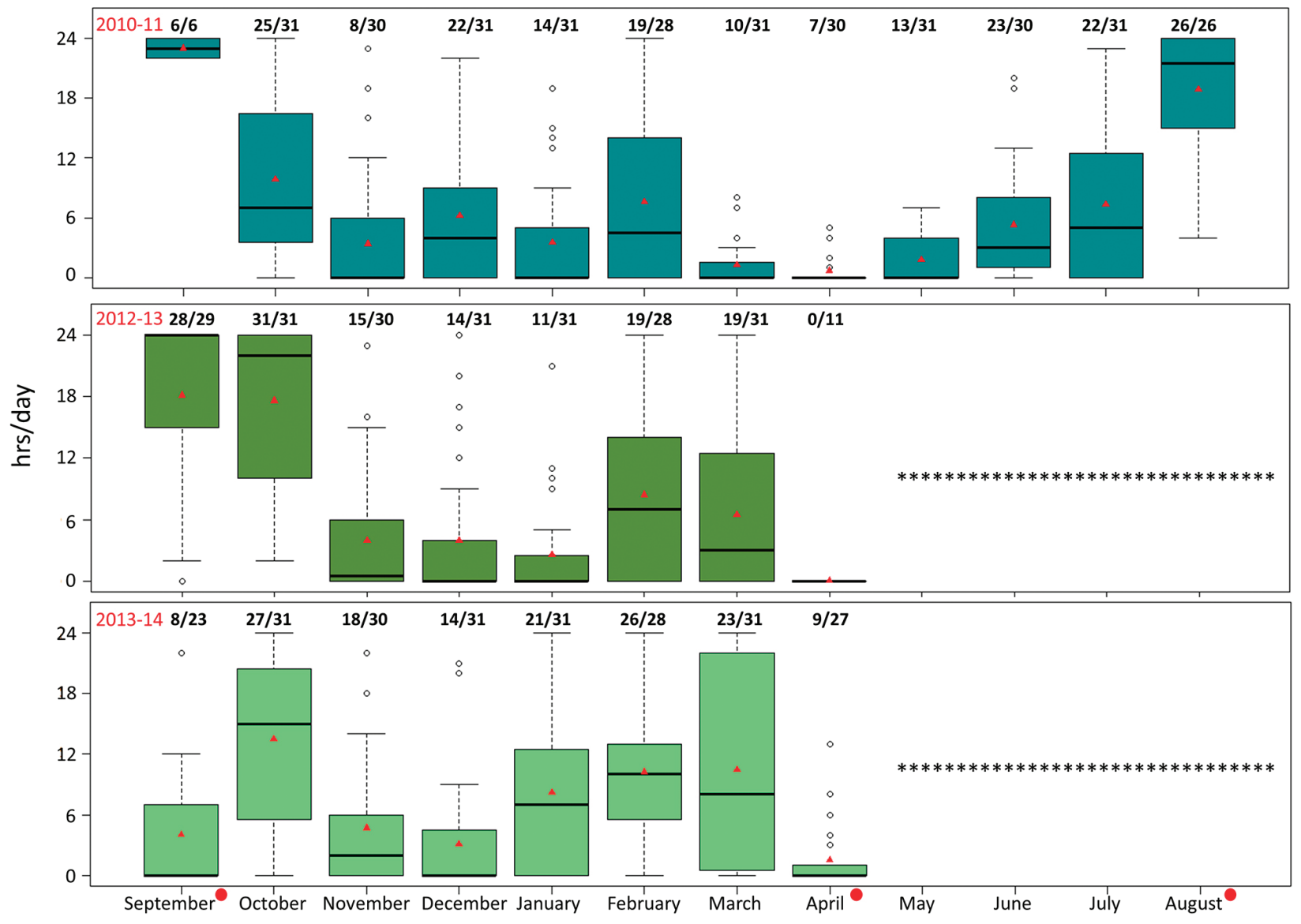

Fig. 3 Mean and median detection levels (hr/day) of narwhal signals by month. Narwhal signals were detected throughout each recording period (except for April 2013). The median level is given by the black thick line and the mean level is indicated by the red triangles. The 25th and 75th percentiles are given by the upper and lower bounds of the box, respectively. Stars indicate months with no data. Red circles indicate that data were not available for the entire month. Numbers above each month bar indicate the number of days with detections and the number of recording days, respectively.

upper $500 \mathrm{~m}$ are shown in Fig. 4. The best-fit GLMM model included all of the predictor variables and the interaction between distance to ice edge and ice-cover category, that is, "broken ice" $(<90 \%)$ or "solid ice" $(\geq 90 \%)$. The highest ice cover had a negative effect on the presence of narwhals; fewer detections of narwhal signals occurred when the ice cover was solid than when it was broken (Table 1, Fig. 4). Distance to the ice edge on its own did not have a significant influence on the presence of narwhals; however, when an interaction with the ice-cover category "solid" was included, a significant negative correlation was found (Table 1, Fig. 4). A positive correlation was found between the percentage of AW and the presence of narwhals (Table 1, Fig. 4).
Table 1 Results of the best-fit generalized linear mixed-effect model for the presence of narwhals (hr/day) as a function of environmental variables.

\begin{tabular}{lllll}
\hline Environmental variable & $\begin{array}{c}\text { Regression } \\
\text { estimate }\end{array}$ & $\begin{array}{c}\text { Standard } \\
\text { error }\end{array}$ & $z$ & $p$ \\
\hline AW percentage & 0.1138 & 0.0426 & 2.67 & 0.00764 \\
Distance (to ice edge) & -0.0535 & 0.0392 & -1.37 & 0.17201 \\
Ice cover_solid & -0.4267 & 0.1034 & -4.13 & $3.70 \mathrm{E}-05$ \\
Distance : Ice Cover_solid & -0.3655 & 0.1044 & -3.50 & 0.00046 \\
\hline
\end{tabular}

GAMM results examining whether there was a variation in acoustic detection of narwhals in relation to the variation in light regime suggest that acoustic signals were more common during daylight and early twilight than during periods of darkness (Fig. 5). 

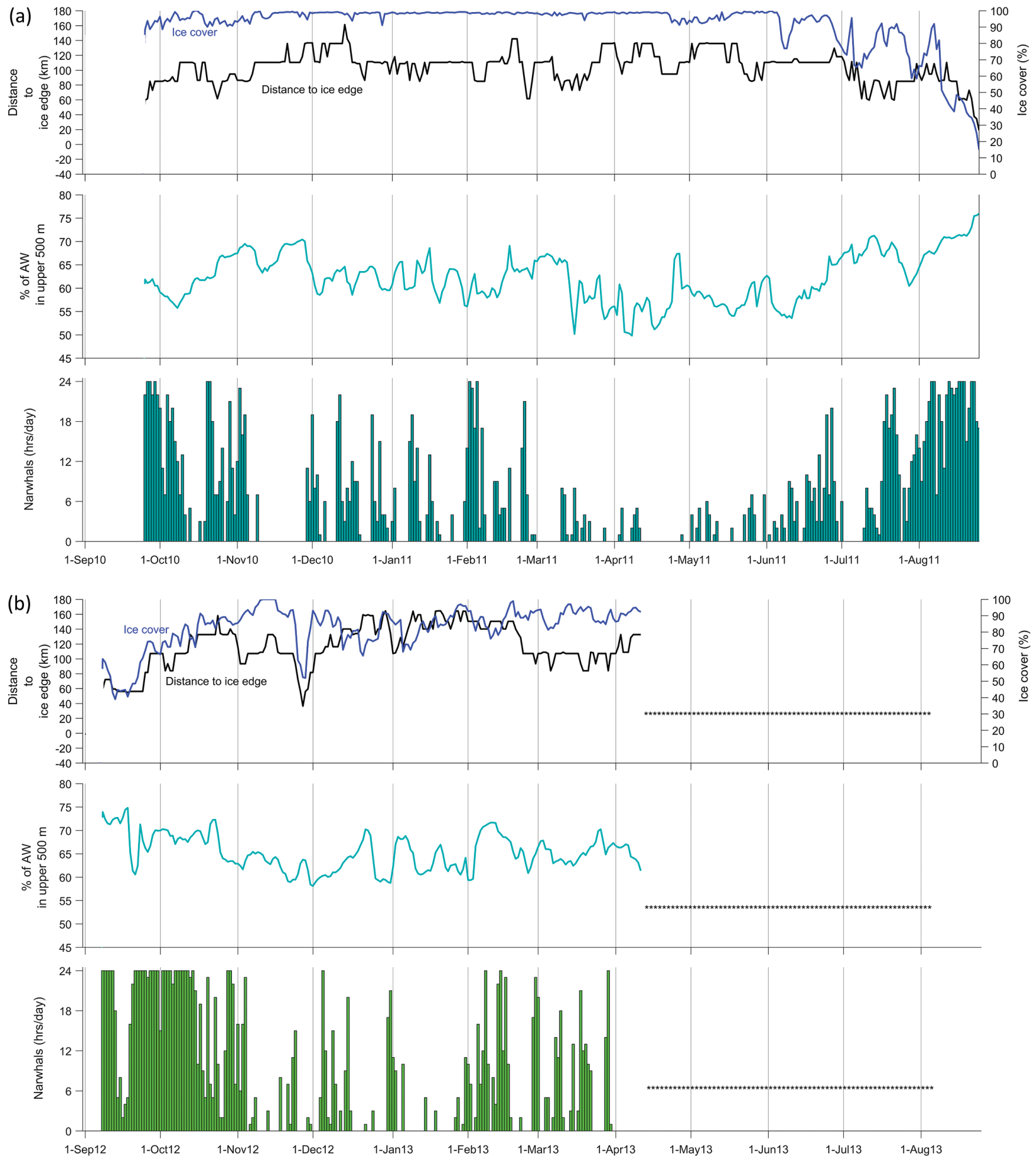

Fig. 4 Daily narwhal detection (hr/day) in western Fram Strait in relation to sea-ice cover (\%), distance to ice edge (km) and the amount of AW (\%) in the upper 500 m (\%) in (a) 2010-11,(b) 2012-13 and (c) 2013-14. Negative distance to ice edge indicates that the mooring is in open water. Stars indicate when data were not available. 
(c)
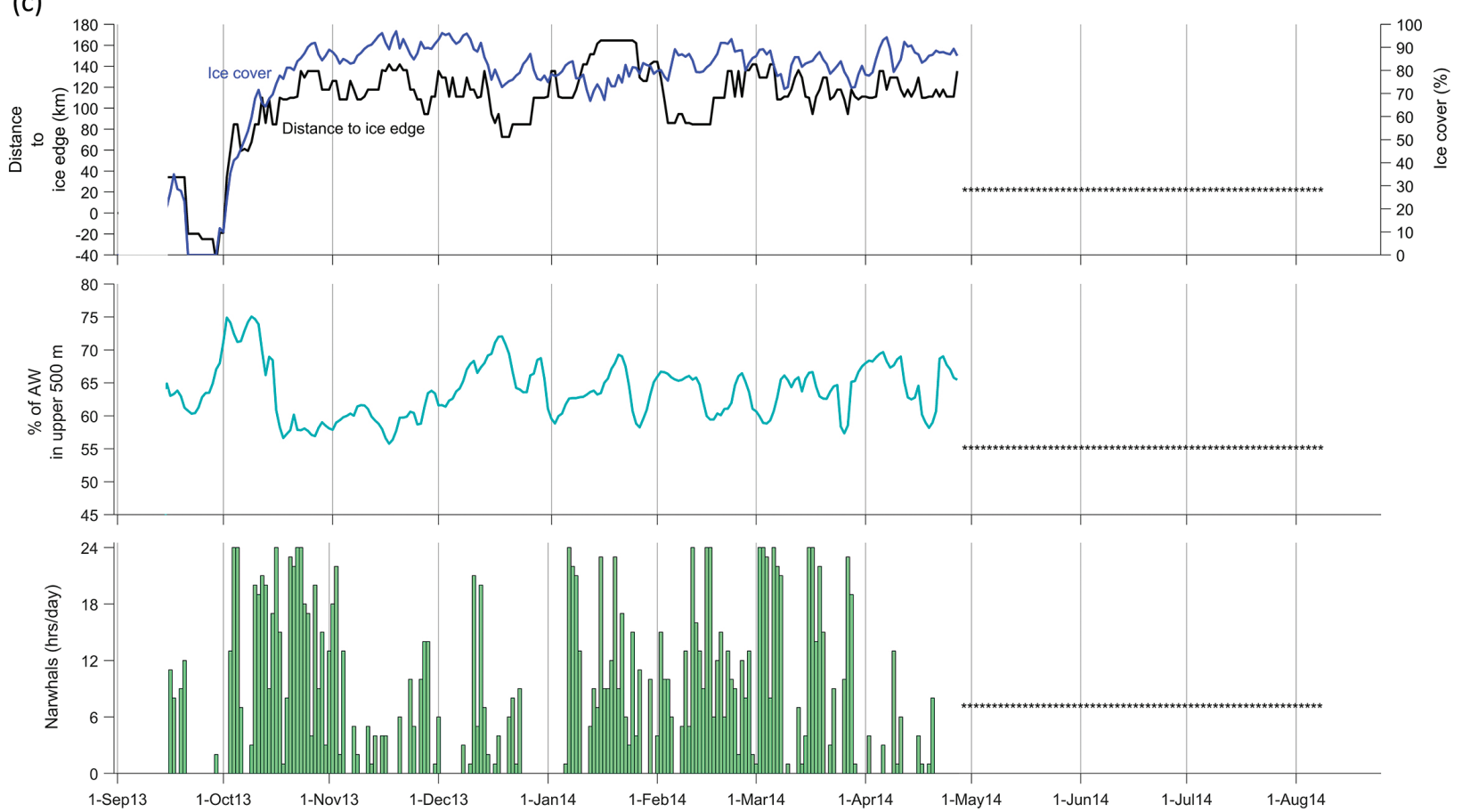

Fig. 4 (Continued) Daily narwhal detection (hr/day) in western Fram Strait in relation to sea-ice cover (\%), distance to ice edge (km) and the amount of AW (\%) in the upper $500 \mathrm{~m}$ (\%) in (a) 2010-11,(b) 2012-13 and (c) 2013-14. Negative distance to ice edge indicates that the mooring is in open water. Stars indicate when data were not available.

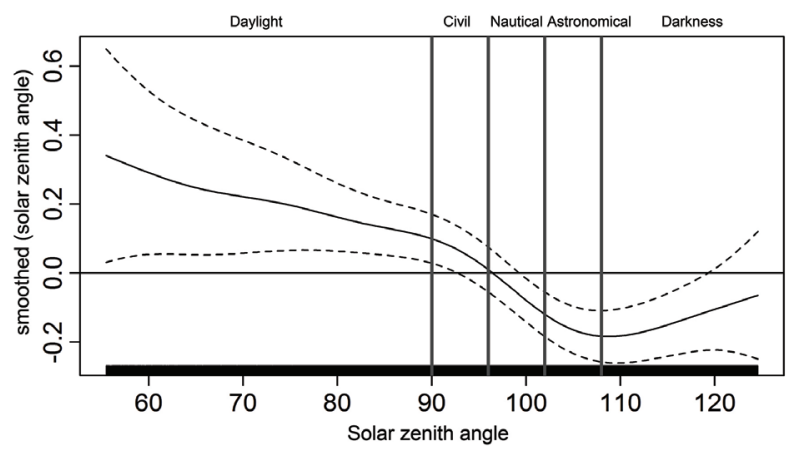

Fig. 5 Results of the generalized additive mixed-effect model on the acoustic presence of narwhals in relation to light regime. Detections were more common during daylight and early twilight times than during periods of darkness.

\section{Discussion}

\section{Year-round occurrence of narwhals in offshore waters}

PAM conducted in western Fram Strait found a yearround acoustic presence of narwhals in deep, offshore ice-covered waters. Even though intra-annual variation in vocal presence was observed, narwhal signals were never absent for long periods (e.g., multiple months). While there are no studies on detection distances for narwhal signals, most odontocete clicks and whistles are not detectable beyond $10 \mathrm{~km}$ (Richardson et al. 1995; Thomsen et al. 2001; Jensen et al. 2012). Recorded animals were therefore likely very close to the AURAL location. Unfortunately, with a single omni-directional instrument it was not possible to determine how many individuals were present or whether acoustic presence came from more than one group of animals. The shorter data collection periods in 2012-13 and 2013-14 meant that data for May-August were available only for the 2010-11 recording period. However, a pilot study conducted in western Fram Strait during 2008-09 reported detection of odontocete signals throughout the year (Moore et al. 2012). Although these signals were assigned to the "generic odontocetes" category, it is likely that all of these signals were from narwhals, as white whales are not known to occur in this area.

Since narwhal pulsed and tonal signals (used for communication) and echolocation clicks (used for navigation and locating prey) are produced year-round (Marcoux, Auger-Méthé \& Humphries 2011; Stafford, Laidre et al. 2012), it is reasonable to postulate that the 
observed acoustic presence is a good proxy for overall occurrence of this species in the area. Furthermore, a recent study of narwhals tagged with short-term acoustic devices in coastal areas of East Greenland showed that narwhal pulsed and tonal signals were recorded most often when the animals were at depths of less than $100 \mathrm{~m}$ (Blackwell et al. 2018), that is, within the same depth range as the hydrophone in the current study $(75 \mathrm{~m})$. The year-round acoustic presence found in this study suggests that narwhals in Fram Strait may behave differently than narwhals studied in other areas, where they have distinct annual movement patterns between deep, offshore, ice-covered wintering grounds, and shallow, coastal, ice-free summering areas. These migration patterns are well described and have been shown to be similar, even between isolated subpopulations (Heide-Jørgensen et al. 2015). Most information on movement patterns of narwhals has been obtained through satellite tracking studies (Heide-Jørgensen et al. 2002; Heide-Jørgensen et al. 2003; Laidre et al. 2004; Heide-Jørgensen, Richard et al. 2013; Heide-Jørgensen et al. 2015), but migration patterns have also been identified using PAM in Baffin Bay and Melville Bay, Canada (Marcoux et al. 2017; Frouin-Mouy et al. 2017). In these latter acoustic studies, narwhal signals were not detected outside the known regional migration times, indicating that the areas were not used during winter or summer.

Narwhals can travel up to ca. $1700 \mathrm{~km}$ between summering and wintering grounds (Heide-Jørgensen, Richard et al. 2013). Given that the distance from the AURAL in the present study to adjacent coastal areas (Svalbard or Greenland) is much shorter than this (ca. 300-350 km), narwhals in the western Fram Strait could easily travel either to Greenland or to Svalbard from the offshore AURAL location. Yet results of this study and the current knowledge of occurrence of narwhals in these coastal areas do not support a routine migration to either area. Several fjords in Svalbard offer deep enough habitats for narwhal and their preferred food items (Dietz et al. 1994), but observations of narwhal in Svalbard's coastal waters are rare (Lydersen et al. 2007; Norwegian Polar Institute's Svalbard Marine Mammal Sightings database [http:// www.npolar.no/en/services/mms/]). In East Greenland, narwhals are found during the summer in fjords from $65^{\circ} \mathrm{N}$ to $81^{\circ} \mathrm{N}$, with the largest concentrations in Scoresby Sound (Heide-Jørgensen 2017). Narwhals from Scoresby Sound are known to travel ca. $350 \mathrm{~km}$ between summering and wintering habitats (Heide-Jørgensen et al. 2015). However, these whales travel south along the continental slope, and it is very unlikely that whales detected in the western Fram Strait are the same whales as those in Scoresby Sound. It is possible that narwhals in fjords north of Scoresby Sound could travel to offshore waters of Fram Strait during winter and be detected by the AURAL. However, considering that narwhal signals were detected throughout the year, it is clear that this is not just a wintering location. Indeed, it is likely that at least some animals or groups of animals reside year round in these offshore waters.

An aerial survey conducted in August 2015 found significant numbers of narwhals north of the Svalbard Archipelago, in water depths exceeding 2000 m, in ice concentrations between $80 \%$ and $100 \%$ (Vacquié-Garcia et al. 2017). These survey results, which are similar to the present acoustic study, suggest that these narwhals spend the summer in habitats described as wintering grounds for other narwhal populations. Thus, both of these data sets suggest that there might be a unique stock, or a fraction of a stock, of narwhals in the Eurasian sector of the Atlantic Arctic that spends most of its time in deep, offshore, ice-covered waters and does not exhibit the "traditional" migratory behaviour involving summer use of coastal shelf areas.

\section{Effects of environmental variables and light regime on the occurrence of narwhals}

Even though narwhals were detected throughout the year, some differences between months and years were observed. The greatest number of hours with detections occurred in late summer/early fall (August through October) and the fewest number of hours occurred in April during each year of the study, suggesting some seasonality to the presence (or acoustic behaviour) of narwhals. Given that the best-fit model found an effect of ice cover, distance to the ice edge and influx of AW on the occurrence of narwhals, the temporal variability observed is likely driven at least in part by environmental fluctuations.

The detections of narwhal signals were most frequent when ice cover was broken $(<90 \%)$. Dense ice cover and long distance to an ice edge in combination are known to create situations in which narwhal are susceptible to entrapment events (Laidre \& Heide-Jørgensen 2005a; Laidre et al. 2012). The results of this study show an inverse relationship between the detection of narwhal signals and distance from the ice edge when the AURAL was in solid ice $(>90 \%)$. Consequently, the sporadic detections of narwhal described during periods where the AURAL was in solid ice might reflect animals moving in and out of the area to avoid entrapment.

Interestingly, narwhal vocal presence in this study was positively correlated with influxes of warm AW. In the Alaskan Beaufort Sea, white whales have been shown to target the boundary between AW and colder winter water where 
their preferred prey is known to aggregate (Crawford et al. 2012; Stafford et al. 2013; Stafford et al. 2016). Whether narwhal in the North-East Atlantic behave in a similar manner is unknown. However, there is evidence from this region that water mass variability (including AW) influences the distribution of both zooplankton species and mesopelagic fish (Daase \& Eiane 2007; Gjøsæeter et al. 2017). It is possible that increased acoustic presence during periods of influxes of warm AW might indicate more narwhal presence due to increases in possible prey in the area. Echolocation clicks and buzzes are generally associated with feeding. However, because the current study included all narwhal sounds and because the sampling rate of the AURAL was not high enough to capture the highest frequencies used by narwhal (e.g., Møhl et al. 1990; Miller et al. 1995; Rasmussen et al. 2015), it was not possible to confirm specific feeding events. Given the highly directional nature of narwhal echolocation, and high sample rates required to capture such sound (Koblitz et al. 2016), it is not clear whether PAM could be used to determine feeding behaviour over annual scales. However, short-term deployments of high-frequency vertical arrays (e.g., Miller et al. 1995; Koblitz et al. 2016) or joint acoustic and satellite tracking studies (Blackwell et al. 2018) in the future might help elucidate narwhal feeding patterns in this offshore habitat.

At the site where the AURAL used in the present study is located $\left(\mathrm{ca} .78^{\circ} 50^{\prime} \mathrm{N}\right)$, seasonal changes in sunlight are extreme-ranging from 0 to $24 \mathrm{hr}$ of daylight (or darkness). In this study, narwhal signals were more frequently recorded during daylight and early twilight than in periods of darkness. This could be an effect of higher ice concentrations during the winter (dark) months, since it was shown here that increased ice cover was negatively correlated with acoustic presence of narwhals. Alternatively, animals may still have been in the area but produced fewer social signals and non-feeding-related echolocation clicks because they were actively foraging or they are foraging at depths outside the detection range of the AURAL during periods of darkness. Indeed, buzzes, which are believed to be used during foraging, were recorded at depths of 350-650 $\mathrm{m}$ from up to six animals instrumented with acoustic tags in East Greenland fjords. These buzzes were recorded more often at night from four of these animals, while calls occurred more often during the late afternoon or evening (see Blackwell et al. 2018).

\section{What makes western Fram Strait a good year-round habitat?}

Narwhals in other areas partition their annual cycle between coastal summering and offshore wintering grounds partly in response to the annual cycle of landfast ice formation and recession in coastal and fjord systems
(Laidre \& Heide-Jørgensen 2005b). Typically, narwhals move out of coastal summering areas in autumn before the formation of landfast ice and migrate into offshore wintering areas. Extreme densities of narwhals have been found in offshore locations and it seems that narwhals choose these optimal foraging habitats despite dense pack ice and limited number of leads and cracks that can lead to sea-ice entrapment (Laidre \& Heide-Jørgensen 2011). Western Fram Strait is covered with heavy sea ice most of the year, but this drifting pack ice is very mobile, which should offer little difficulty for narwhals in terms of finding open cracks or leads for breathing, as well as presenting little risk of ice entrapment (unless it is solid, with $>90 \%$ ice cover). Occupying this ice-covered area provides narwhals with good protection from their open-water predator, the killer whale (Orcinus orca; Breed et al. 2017), bad weather conditions (dampening wave action) and anthropogenic disturbances. In addition, if narwhals occupy this area on a year-round basis, it must also provide sufficient food. The location of the AURAL is on the slope of the continental shelf at a bottom depth of about $1000 \mathrm{~m}$ (maximum depth of the strait is around $2650 \mathrm{~m}$ ) and topographic features such as continental shelves often attract zooplankton and fish to take advantage of primary production fuelled by the upwelling of nutrients. Hence, such areas are often also used by marine mammals. Additionally, the Fram Strait is the deepest gateway to the Arctic Ocean, where the exchange of cold PW and warm AW occurs. At times, warm eddies pass by the AURAL's location, originating from the Polar Front between the cold PW and the warm AW that recirculates in Fram Strait. The meeting of these two different water masses creates a very dynamic frontal environment. Such dynamic oceanographic features are known to positively influence prey densities and structure Arctic habitats (Daase \& Eiane 2007; Laidre et al. 2008; Crawford et al. 2012; Stafford et al. 2013).

\section{Narwhals, climate change and anthropogenic disturbance in western Fram Strait}

Narwhals are considered to be one of the most vulnerable Arctic species to climate change effects because they have low genetic diversity, a limited range and a relatively narrow dietary niche, and they show high site fidelity and are highly sensitive to environmental changes (Palsbøll et al. 1997; Laidre \& Heide-Jørgensen 2005a, b; Laidre et al. 2008). The Barents/Greenland Sea region is experiencing the most rapid declines in the seasonal extent of sea ice compared to all other regions in the Arctic (Kelly et al. 2010; Pavlov et al. 2013; Nordli et al. 2014; Onarheim et al. 2014; Laidre et al. 2015). The inevitable reduction in sea-ice cover and the absence of summer ice are likely to result not only in reduced habitat for narwhals in this 
region, but also an increase in the likelihood of competition for prey as temperate species expand into more northerly latitudes (Storrie et al. 2018) and increased risks from open-water predators (killer whales). The changes in sea-ice cover will undoubtedly also increase human activities, including commercial shipping and fisheries, oil and gas exploration and tourism, unless management actions limit these activities (Reeves et al. 2014). Until recently, perennial ice cover has kept western Fram Strait relatively free of anthropogenic disturbance (Ahonen et al. 2017). Currently, sea ice is still present in this region throughout the year (70-100\% sea-ice cover for most months). During this study, there were only 11 days during which the AURAL was in open water (21 September-1 October 2013). Interestingly, this open-water period in 2013 was a period when an airgun survey was conducted close to the AURAL site: from 25 September to 4 October, a seismic survey vessel was within $100 \mathrm{~km}$ of the mooring, coming as close as $57 \mathrm{~km}$ on 27 September 2013 (Ahonen et al. 2017). The detection frequency of narwhals was lower during this same period in 2013 compared to the other years in the study, but no firm conclusions can be drawn from this anecdotal observation. The petroleum industry is already expanding into the North-East Atlantic and Greenland has issued a large number of exploratory licenses in East Greenland. This increase in human activity will almost certainly have negative effects on narwhal (Boertmann \& Moscbech 2012). Given the narwhals' recently documented energetically costly escape response (Williams et al. 2017), and sensitivity to anthropogenic disturbances (Heide-Jørgensen, Hansen et al. 2013), documenting annual and seasonal habitat requirements of this Arctic endemic species, and protecting them against unacceptable levels of anthropogenic disturbance, is essential at this time.

\section{Acknowledgements}

The authors thank Kristen Fossan (Norwegian Polar Institute) for servicing the western Fram Strait AURAL annually. They also thank Jade Vacquié-Garcia and Andrew Lowther for advice with the model design.

\section{Disclosure statement}

No potential conflict of interest was reported by the authors.

\section{Funding}

This work has been funded by the Fram Centre MIKON programme, the Svalbard Environmental Protection Fund, the Svalbard Science Forum, the Fram Centre Incentive Fund, the Norwegian Polar Institute and the ICE-whales research programme, which is financed by the Norwegian Research Council (grant no. 244488/E10).

\section{References}

Aagaard K. \& Coachman L.K. 1968. The East Greenland current north of Denmark Strait: part I. Arctic 21, 181-200, http://dx.doi.org/10.14430/arctic3262.

Ahonen H., Stafford K.M., de Steur L., Lydersen C., Wiig Ø. \& Kovacs K.M. 2017. The underwater soundscape in western Fram Strait: breeding ground of Spitsbergen's endangered bowhead whales. Marine Pollution Bulletin 123, 97-112, http://dx.doi.org/10.1016/j.marpolbul.2017.09.019.

Beszczynska-Möller A., Fahrbach E., Schauer U. \& Hansen E. 2012. Variability in Atlantic Water temperature and transport at the entrance to the Arctic Ocean, 1997-2010. ICES Journal of Marine Science 69, 852-863, http://dx.doi. org/10.1093/icesjms/fss056.

Blackwell S.B., Tervo O.M., Conrad A.S., Sinding M.H.S., Hansen R.G., Ditlevsen S. \& Heide-Jørgensen M.P. 2018. Spatial and temporal patterns of sound production in East Greenland narwhals. PLoS One 13, e0198295, http://dx. doi.org/10.1371/journal.pone.0198295.

Boertmann D. \& Mosbech A. 2012. The western Greenland Sea: a strategic environmental impact assessment of hydrocarbon activities. Scientific Report from Danish Centre for Environment and Energy 22. Aarhus: Danish Centre for Environment and Energy, Aarhus University.

Bourke R., Weigel A. \& Paquette R. 1988. The westward turning branch of the West Spitsbergen current. Journal of Geophysical Research-Oceans 93, 14065-14077, http:// dx.doi.org/10.1029/JC093iCl 1pl4065.

Breed G.A., Matthews C.J., Marcoux M., Higdon J.W., LeBlanc B., Petersen S.D., Orr J., Reinhart N.R. \& Ferguson S.H. 2017. Sustained disruption of narwhal habitat use and behavior in the presence of Arctic killer whales. Proceedings of the National Academy of Sciences of the United States of America 114, 2628-2633, http://dx.doi. org/10.1073/pnas.1611707114.

Cavalieri D.J., Markus T. \& Comiso J.C. 2014. AMSR-E/Aqua daily L3 $25 \mathrm{~km}$ brightness temperature \& sea ice concentration polar grids, version 3. NASA National Snow and Ice Data Center Distributed Active Archive Center, Boulder, CO. http://dx.doi.org/10.5067/AMSR-E/AE_SI25.003. Accessed on the internet at https://nsidc.org/data/ae_sil2 on 31 August 2016.

Crawford R., Vagle S. \& Carmack E. 2012. Water mass and bathymetric characteristics of polar cod habitat along the continental shelf and slope of the Beaufort and Chukchi seas. Polar Biology 35, 179-190, http://dx.doi.org/10.1007/ s00300-011-1051-9.

Daase M. \& Eiane K. 2007. Mesozooplankton distribution in northern Svalbard waters in relation to hydrography. Polar Biology 30, 969-981, http://dx.doi.org/10.1007/ s00300-007-0255-5. 
de Steur L., Hansen E., Gerdes R., Karcher M., Fahrbach E. \& Holfort J. 2009. Freshwater fluxes in the East Greenland Current: a decade of observations. Geophysical Research Letters 36, L23611, http://dx.doi.org/10.1029/ 2009GL041278.

Dietz R., Heide-Jørgensen M.P., Born E.W. \& Glahder C.M. 1994. Occurrence of narwhals (Monodon monoceros) and white whales (Delphinapterus leucas) in East Greenland. Meddelelser om Grønland Bioscience 39, 69-86.

Dietz R., Heide-Jørgensen M.P., Richard P.R. \& Acquarone M. 2001. Summer and fall movements of narwhals (Monodon monoceros) from northeastern Baffin Island towards northern Davis Strait. Arctic 54, 244-261, http://dx.doi.org/10.14430/ arctic785.

Fetterer F., Knowles K., Meier W., Savoie M. \& Windnagel A.K. 2017. Sea ice index, version 3. National Snow and Ice Data Center, Boulder, CO. http://dx.doi.org/10.7265/ N5K072F8. Accessed on the internet at https://nsidc.org/ data/g02135 on 16 November 2017.

Ford J. \& Fisher H.D. 1978. Underwater acoustic signals of narwhal (Monodon monoceros). Canadian Journal of Zoology 56, 552-560, http://dx.doi.org/10.1139/z78-079.

Frouin-Mouy H., Kowarski K., Martin B. \& Bröker K. 2017. Seasonal trends in acoustic detection of marine mammals in Baffin Bay and Melville Bay, northwest Greenland. Arctic 70, 59-76, http://dx.doi.org/10.14430/arctic4632.

Gjøsæter H., Wiebe P.H., Knutsen T. \& Ingvaldsen R.B. 2017. Evidence of diel vertical migration of mesopelagic soundscattering organisms in the Arctic. Frontiers in Marine Science 4, article no. 1177, http://dx.doi.org/10.3389/fmars. 2017.00332.

Heide-Jørgensen M.P. 2017. Narwhal Monodon monoceros. In B. Würsig et al. (eds.): Encyclopedia of marine mammals. Pp. 627-631. San Diego, CA: Academic Press.

Heide-Jørgensen M.P. \& Dietz R. 1995. Some characteristics of narwhal, Monodon monoceros, diving behaviour, in Baffin Bay. Canadian Journal of Zoology 73, 2120-2132, http://dx. doi.org/10.1139/z95-249.

Heide-Jørgensen M.P., Dietz R., Laidre K. \& Richard P. 2002. Autumn movements, home ranges, and winter density of narwhals (Monodon monoceros) tagged in Tremblay Sound, Baffin Island. Polar Biology 25, 331-341.

Heide-Jørgensen M.P., Dietz R., Laidre K.L., Richard P., Orr J. \& Schmidt H.C. 2003. The migratory behaviour of narwhals (Monodon monoceros). Canadian Journal of Zoology 81, 1298-1305, http://dx.doi.org/10.1139/Z03-117.

Heide-Jørgensen M.P., Hansen R.G., Westdal K., Reeves R.R. \& Mosbech A. 2013. Narwhals and seismic exploration: is seismic noise increasing the risk of ice entrapments? Biological Conservation 158, 50-54, http://dx.doi. org/10.1016/j.biocon.2012.08.005.

Heide-Jørgensen M.P., Nielsen N.H., Hansen R.G., Schmidt H.C., Blackwell S.B \& Jørgensen O.A. 2015. The predictable narwhal: satellite tracking shows behavioural similarities between isolated subpopulations. Journal of Zoology 297, 54-65, http://dx.doi.org/10.1111/jzo.12257.

Heide-Jørgensen M.P., Richard P.R., Dietz R. \& Laidre K.L. 2013. A metapopulation model for Canadian and West
Greenland narwhals. Animal Conservation 16, 331-343, http://dx.doi.org/10.1111/acv.12000.

Jensen F.H., Beedholm K., Wahlberg M., Bejder L. \& Madsen P.T. 2012. Estimated communication range and energetic cost of bottlenose dolphin whistles in a tropical habitat. Journal of the Acoustical Society of America 131, 582-592, http://dx.doi.org/10.1121/1.3662067.

Kelly B., Bengtson J.L., Boveng P.L., Cameron M.F., Dahle S.P., Jansen J.K., Logerwell E.A., Overland J.E., Sabine C.L., Waring G.T. \& Wilder J.M. 2010. Status report on ringed seals (Phoca hispida). NOAA Technical Memorandum NMFSAFSC-212. Springfield, VA: US Dept of Commerce.

Koblitz J.C., Stilz P., Rasmussen M.H. \& Laidre K.L. 2016. Highly directional sonar beam of narwhals (Monodon monoceros) measured with a vertical 16 hydrophone array. PLoS One 11, e0162069, http://dx.doi.org/10.1371/journal.pone.0162069.

Laidre K.L. \& Heide-Jørgensen M. 2005a. Arctic sea ice trends and narwhal vulnerability. Biological Conservation 121, 509-517, http://dx.doi.org/10.1016/j.biocon.2004.06.003.

Laidre K.L. \& Heide-Jørgensen M. 2005b. Winter feeding intensity of narwhals (Monodon monoceros). Marine Mammal Science 21, 45-57, http://dx.doi.org/10.1111/j.1748-7692.2005. tb01207.x.

Laidre K.L. \& Heide-Jørgensen M.P. 2011. Life in the lead: extreme densities of narwhals Monodon monoceros in the offshore pack ice. Marine Ecology Progress Series 423, 269-278, http://dx.doi.org/10.3354/meps08941.

Laidre K.L., Heide-Jørgensen M.P., Dietz R., Hobbs R. \& Jørgensen O.A. 2003. Deep-diving by narwhals Monodon monoceros: differences in foraging behavior between wintering areas? Marine Ecology Progress Series 261, 269-281, http://dx.doi.org/10.3354/meps261269.

Laidre K.L., Heide-Jørgensen M.P., Logdson M.L., Hobbs R.C., Heagerty P., Dietz R., Jørgensen O.A. \& Treble M.A. 2004. Seasonal narwhal habitat associations in the High Arctic. Marine Biology 145, 821-831, http://dx.doi.org/10.1007/ s00227-004-1371-1.

Laidre K.L., Heide-Jørgensen M.P., Stern H. \& Richard P. 2012. Unusual narwhal sea ice entrapments and delayed autumn freeze-up trends. Polar Biology 35, 149-154, http:// dx.doi.org/10.1007/s00300-011-1036-8.

Laidre K.L., Stern H., Kovacs K.M., Lowry L., Moore S.E., Regehr E.V., Ferguson S., Wiig Ø., Boveng P.L., Angliss R., Born E.W., Litovka D., Quakenbush L., Lydersen C., Vongraven D. \& Ugarte F. 2015. Arctic marine mammal population status, sea ice habitat loss, and conservation recommendations for the 21 st century. Conservation Biology 29, 724-737, http://dx.doi.org/10.1111/cobi.12474.

Laidre K.L., Stirling I., Lowry L.F., Wiig Ø., Heide-Jørgensen M.P. \& Ferguson S.H. 2008. Quantifying the sensitivity of Arctic marine mammals to climate-induced habitat change. Ecological Applications 18, S97-S125, http://dx.doi. org/10.1890/06-0546.1.

Lydersen C., Martin A.R., Gjertz I. \& Kovacs K.M. 2007. Satellite tracking and diving behaviour of sub-adult narwhals (Monodon monoceros) in Svalbard, Norway. Polar Biology 30 , 437-442, http://dx.doi.org/10.1007/s00300-006-0200-z. 
MacIntyre K.Q., Stafford K.M., Conn P.B., Laidre K.L. \& Boveng P.L. 2015. The relationship between sea ice concentration and the spatio-temporal distribution of vocalizing bearded seals (Erignathus barbatus) in the Bering, Chukchi, and Beaufort seas from 2008 to 2011. Progress in Oceanography 136, 241-249, http://dx.doi.org/10.1016/j. pocean.2015.05.008.

Marcoux M., Auger-Methe M., Chmelnitsky E.G., Ferguson S.H. \& Humphries M.M. 2011 . Local passive acoustic monitoring of narwhal presence in the Canadian Arctic: a pilot project. Arctic 64, 307-316, http://dx.doi.org/10.14430/ $\operatorname{arctic} 4121$.

Marcoux M., Auger-Méthé M. \& Humphries M.M. 2011. Variability and context specificity of narwhal (Monodon monoceros) whistles, and pulsed calls. Marine Mammal Science 28, 649-665, http://dx.doi.org/10.1111/j.1748-7692. $2011.00514 . x$.

Marcoux M., Ferguson S.H., Roy N., Bedard J.M. \& Simard Y. 2017. Seasonal marine mammal occurrence detected from passive acoustic monitoring in Scott Inlet, Nunavut, Canada. Polar Biology 40, 1127-1138, http://dx.doi.org/ 10.1007/s00300-016-2040-9.

Miller L.A., Pristed J., Møshl B. \& Surlykke A. 1995. The click-sounds of narwhals (Monodon monoceros) in Inglefield Bay, northwest Greenland. Marine Mammal Science 11, 491-502, http://dx.doi.org/10.1111/j.1748-7692.1995. tb00672.x.

Møhl B., Surlykke A. \& Miller L.A. 1990. High intensity narwhal clicks. In J.A. Thomas \& R.A. Kastelein (eds.): Sensory abilities of cetaceans. Pp. 295-303. New York: Plenum Press.

Moore S.E., Stafford K.M., Melling H., Berchok C., Wiig Ø., Kovacs K.M., Lydersen C. \& Richter-Menge J. 2012. Comparing marine mammal acoustic habitats in Atlantic and Pacific sectors of the High Arctic: year-long records from Fram Strait and the Chukchi Plateau. Polar Biology 35, 475-480, http://dx.doi.org/10.1007/ s00300-016-2040-9.

Mosby H. 1962. Water, salt, and heat balance of the North Polar Sea and of the Norwegian Sea. Geofysiske Publikasjoner, Geophysica Norvegica 24, 289-313.

Nordli Ø., Przybylak R., Ogilvie A.E.J. \& Isaksen K. 2014. Long-term temperature trends and variability on Spitsbergen: the extended Svalbard Airport temperature series, 1898-2012. Polar Research 33, article no. 21349, http://dx. doi.org/10.3402/polar.v33.21349.

Onarheim I.H., Smedsrud L.H., Invaldsen R. \& Nilsen F. 2014. Loss of sea ice during winter north of Svalbard. Tellus A 66, article no. 23933, http://dx.doi.org/10.3402/ tellusa.v66.23933.

Palsbøll P.J., Heide-Jørgensen M.P. \& Dietz R. 1997. Population structure and seasonal movements of narwhals, Monodon monoceros, determined from mtDNA analysis. Heredity 78 , 284-292, http://dx.doi.org/10.1038/hdy.1997.43.

Pavlov A.K., Tverberg V., Ivanov B.V., Nilsen F., Falk-Petersen S. \& Granskog M.A. 2013. Warming of Atlantic Water in two west Spitsbergen fjords over the last century (1912-2009). Polar Research 32, article no. 11206, http:// dx.doi.org/10.3402/polar.v32i0.11206.
Rasmussen M.H., Koblitz J.C. \& Laidre K.L. 2015. Buzzes and high-frequency clicks recorded from narwhals (Monodon monoceros) at their wintering ground. Aquatic Mammals 41, 256-264, http://dx.doi.org/10.1578/AM. 41.3.2015.256.

Reeves R.R., Ewins P.J., Agbayani S., Heide-Jørgensen M.P., Kovacs K.M., Lydersen C., Suydam R., Elliott W., Polet G., van Dijk Y. \& Blijleven R. 2014. Distribution of endemic cetaceans in relation to hydrocarbon development and commercial shipping in a warming Arctic. Marine Policy 44, 375-389, http://dx.doi.org/10.1016/j. marpol.2013.10.005.

Richardson W.J., Greene C.R., Malme C.I. \& Thomson D.H. 1995. Marine mammals and noise. San Diego, CA: Academic Press.

Roy N., Simard Y. \& Gervaise C. 2010. 3D tracking of foraging belugas from their clicks: experiment from a coastal hydrophone array. Applied Acoustics 71, 1050-1056, https:// doi.org/10.1016/j.apacoust.2010.05.008.

Shapiro A.D. 2006. Preliminary evidence for signature vocalizations among free-ranging narwhals (Monodon monoceros). Journal of the Acoustical Society of America 120, 1695-1705, http://dx.doi.org/10.1121/1.2226586.

Sjare B.L. \& Smith T.G. 1986. The vocal repertoire of white whales, Delphinapterus leucas, summering in Cunningham Inlet, Northwest Territories. Canadian Journal of Zoology 64, 407-415, https://doi.org/10.1139/z86-063.

Stafford K.M., Citta J.J., Okkonen S.R. \& Suydam R.S. 2016. Wind-dependent beluga whale dive behavior in Barrow Canyon, Alaska. Deep-Sea Research Part II 118, 57-65, http://dx.doi.org/10.1016/j.dsr.2016.10.006.

Stafford K.M., Laidre K.L. \& Heide-Jørgensen M.P. 2012. First acoustic recordings of narwhals (Monodon monoceros) in winter. Marine Mammal Science 28, E197-E207, http://dx.doi.org/10.1111/j.1748-7692.2011. 00500.x.

Stafford K.M., Lydersen C., Wiig Ø. \& Kovacs K.M. 2018. Extreme diversity in the songs of Spitsbergen's bowhead whales. Biology Letters 14, article no. 20180056, http://dx. doi.org/10.1098/rsbl.2018.0056.

Stafford K.M., Moore S.E., Berchok C.L., Wiig Ø., Lydersen C., Hansen E., Kalmbach D. \& Kovacs K.M. 2012. Spitsbergen's endangered bowhead whales sing through the polar night. Endangered Species Research 18, 95-103, http://dx.doi. org/10.3354/esr00444.

Stafford K.M., Okkonen S.R. \& Clarke J.T. 2013. Correlation of a strong Alaska Coastal Current with the presence of beluga whales Delphinapterus leucas near Barrow, Alaska. Marine Ecology Progress Series 474, 287-297, http://dx.doi. org/10.3354/meps 10076.

Storrie L., Lydersen C., Andersen M., Wynn R.B. \& Kovacs K.M. 2018. Determining the species assemblage and habitat use of cetaceans in the Svalbard Archipelago, based on recorded observations from 2002-2014. Polar Research 37, article no. 1463065, http://dx.doi.org/10.1080/17518369. 2018.1463065.

Thomsen F., Franck D. \& Ford J.K.B. 2001. Characteristics of whistles from the acoustic repertoire of resident killer 
whales (Orcinus orca) off Vancouver Island, British Columbia. Journal of the Acoustical Society of America 109, 1240-1246, http://dx.doi.org/10.1121/1.1349537.

Vacquié-Garcia J., Lydersen C., Marques T.A., Aars J., Ahonen H., Skern-Mauritzen M., Oien N. \& Kovacs K.M. 2017. Late summer distribution and abundance of iceassociated whales in the Norwegian High Arctic. Endangered Species Research 32, 59-70, http://dx.doi.org/10.3354/ esr00791.
Watt C.A., Heide-Jørgensen M.P. \& Ferguson S.H. 2017. Spatial distribution of narwhal (Monodon monoceros) diving for Canadian populations helps identify important seasonal foraging areas. Canadian Journal of Zoology 95, 41-50, http://dx.doi.org/10.1139/cjz-2016-0178.

Williams T.M., Blackwell S.B., Richter B., Sinding M.-H.S. \& Heide-Jørgensen M.P. 2017. Paradoxical escape responses by narwhals (Monodon monoceros). Science 358, 1328-1331, http://dx.doi.org/10.1126/science.aao2740. 